\title{
Low-energy femoral shaft fracture in elderly patient with prolonged use of alendronate
}

Fraturas diafisárias do fêmur por baixa energia nos pacientes idosos

com uso prolongado de alendronato

José Ricardo Negreiros Vicente ${ }^{1}$, Daniel Seguel Rebolledo 2 , Marcos Camargo Leonhardt ${ }^{3}$, Mauricio Bernstein ${ }^{4}$

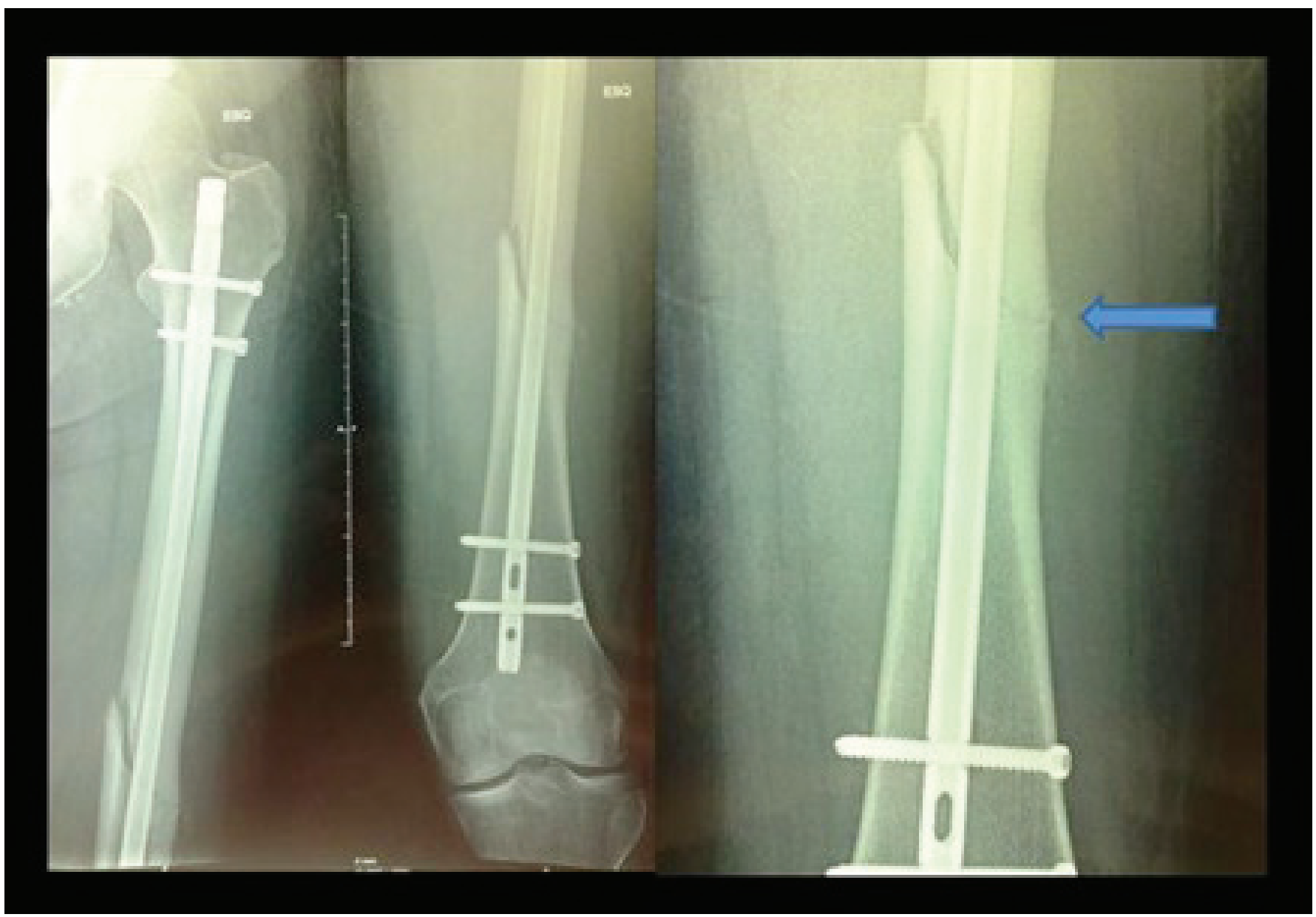

Figure 1. Stress fracture in the lateral córtex.

\footnotetext{
Study carried at Hospital Israelita Albert Einstein - HIAE, São Paulo (SP), Brasil.

'Othopedic Oncology Group, Faculdade de Medicina, Universidade de São Paulo - USP, São Paulo (SP), Brazil.

${ }^{2}$ Orthopedic Oncology Group, Faculdade de Medicina do ABC - FMABC, Santo André (SP), Brazil; Master's degree student at the Department of Orthopedics and Trauma, Faculdade de Medicina, Universidade de São Paulo - USP, São Paulo (SP), Brazil.

${ }^{3}$ Hip Group, Department of Orthopedics and Trauma, Faculdade de Medicina, Universidade de São Paulo - USP, São Paulo (SP), Brazil.

${ }^{4}$ Department of Cardiopneumology, Faculdade de Medicina, Universidade de São Paulo - USP, São Paulo (SP), Brazil; Cardiologist at the Hospital Israelita Albert Einstein - HIAE, São Paulo (SP), Brazil. Corresponding author: José Ricardo Negreiros Vicente - Rua Afonso de Freitas, 488, apto. 22 - Paraíso - CEP 04006-052 - São Paulo (SP), Brasil - Tel.: 11 3884-0665 - e-mail: jrnegreiro@einstein.br Received on Jun 30, 2009 - Accepted on Apr 12, 2010

The authors declare there is no conflict of interest.
} 
Fractures in the proximal femur occur in female and male elderly population due to low-energy trauma in osteoporotic bones. In order to prevent these fractures, treatment of osteoporosis has been indicated, particularly using biphosphonates ${ }^{(1)}$.

Alendronate was the first drug approved by the Food and Drug Administration (FDA), in 1995, to treat osteoporosis $^{(2)}$. This drug acts in bone metabolism, inhibiting osteoclasts, inducing their apoptosis ${ }^{(3)}$, raising the bone mineral density and reducing the incidence of osteoporotic fractures $^{(4)}$.

In the past years, some authors described an unusual shaft femoral fracture in elderly women undergoing prolonged treatmentofosteoporosis withbiphosphonates. These fractures were associated with low-energy trauma or no evidence of any trauma event ${ }^{(5,6)}$.

Femoral structure submitted to physiological stress results in microdamages to bone microstructure. The inhibition of osteoclasts may also lead to severe suppression in bone turnover, leading to accumulation of microdamage ${ }^{(7-9)}$. These processes may make bone brittle and cause unexpected and uncommon femoral fractures.

A recent increase in the incidence of such fractures in patients on alendronate therapy led some authors to conduct a retrospective review of these cases. A characteristic fracture configuration suggestive of an insufficiency stress fracture was identified on plain radiographs. This consists of a cortical thickening in the lateral side of the subtrochanteric region, a transverse or short oblique fracture, and a medial cortical spike (Figure 1).
A retrospective study evaluating 19 patients with this fracture pattern among 70 patients with low-energy shaft fractures was $98 \%$ specific to alendronate users ${ }^{(6)}$. Thus, alendronate treatment might be stopped for a while after five years to prevent severe suppression of bone turnover and subsequent stress fractures ${ }^{(7)}$.

\section{REFERENCES}

1. Dinçel E, Sepici-Dinçel A, Sepici V, Özsoy H, Sepici B. Hip fracture risk and different gene polymorphisms in the Turkish population. Clinics. 2008;63(5): $645-50$.

2. FDA- approved Drugs. USA Food and Drug Administration 1995 (date last accessed $1^{\text {st }}$ February 2007).

3. Fleisch H, Reszka A, Rodan G, Rogers M. Bisphosphonates: mechanisms of action. In: Bilezikian JP. Principles of bone biology. 2nd ed. San Diego: Academic Press; 2002. Vol. 1. p. 1361-85.

4. Wells GA, Cranney A, Peterson J, Boucher M, Shea B, Robinson V, Coyle D et al. Alendronate for the primary and secondary prevention of osteoporotic fracture in postmenopausal women. Cochrane Database Syst Rev. 2008; (1):CD001155

5. Lenart BA, Lorich DG, Lane JM. Atypical fractures of the femoral diaphysis in postmenopausal women taking alendronate. N Engl J Med. 2008;358(12)1304-6.

6. Neviaser AS, Lane JM, Lenart BA, Edobor-Osula F, Lorich DG. Low-energy femoral shaft fractures associated with alendronate use. J Orthop Trauma. 2008;22(5):346-50.

7. Yamaguchi T, Sugimoto T. [New development in bisphosphonate treatment. When and how long should patients take bisphosphonates for osteoporosis?]. Clin Calcium. 2009;19(1):38-43. [Japanese].

8. Goh SK, Yang KY, Koh JSB, Wong MK, Chua DT, Howe TS. Subtrochanteric insufficiency fractures in patients on alendronate therapy: A CAUTION. J Bone Joint Surg Br. 2007;89(3):349-53.

9. Visekruna M, Wilson D, McKiernan FE. Severely suppressed bone turn over and atypical skeletal fragility. J Clin Endocrinol Metab. 2008;93(8):2948-52. 